\title{
Bentuk Kegiatan Diversi Anak dalam Undang-undang Nomor 11 Tahun 2012 tentang Sistem Peradilan Pidana Anak.
}

\author{
Nurini Aprilianda \\ Fakultas Hukum Universitas brawijaya \\ aprilianda@yahoo.co.id ; nurini.aprilianda@ub.ac.id
}

\begin{abstract}
This paper aims to explore, analyze and find the urgency and child diversion activity in the form of patterns on investigation level that reflects the legal politics of the UU SPPA. This paper is based on normative legal research with statutory approach and comparative approach. The result of the research shows that the form of diversion implementation in Indonesia can be considered through the development of education and training for children such as facilities for children for 4 (four) types of activities such as sports, recreation, assistance programs and art. In Indonesia, these activities can be done by establishing cooperation with social agencies and NGOs. Furthermore, the activities that given to children are adjusted to the region's characteristic and adjust their talents and interests.
\end{abstract}

Keywords: diversion, child, development of education.

\begin{abstract}
Abstrak
Tulisan ini bertujuan untuk menggali, menganalisis dan menemukan urgensi dan pola bentuk kegiatan diversi anak pada tingkat penyidikan yang mencerminkan politik hukum UU SPPA. Tulisan ini dibuat berdasarkan penelitian hukum normatif dengan pendekatan peraturan perundang-undangan (statute approach) dan pendekatan perbadingan (comparative approach). Hasil penelitian menunjukkan bahwa bentuk pelaksanaan diversi di Indonesia dapat dipertimbangkan melalui pengembangan pendidikan dan pelatihan bagi anak misalnya fasilitas bagi anak untuk 4 (empat) jenis aktivitas yaitu olahraga, rekreasi, assistance programs dan kesenian. Di Indonesia, kegiatan tersebut dapat dilakukan dengan menjalin kerjasama dengan dinas sosial dan LSM. Selanjutnya kegiatan yang diberikan pada anak disesuaikan dengan karakteristik daerah dan menyesuaikan bakat dan minat anak.
\end{abstract}

Kata kunci : diversi, anak, pengembangan dan pendidikan.

Pendahuluan

Undang-Undang Nomor 11

Tahun 2012 tentang Sistem

Peradilan Pidana Anak (selanjutnya

disebut UU SPPA) menggantikan
Undang-undang Nomor 3 Tahun

1997 tentang Pengadilan Anak yang dilakukan dengan tujuan agar dapat terwujud peradilan yang benar-benar menjamin pelindungan kepentingan 
terbaik terhadap Anak yang berhadapan dengan hukum sebagai penerus bangsa.

Hal baru yang menarik dalam UU SPPA adalah pengaturan masalah diversi yang ditawarkan dalam setiap tahap sistem peradilan pidana. Anak-anak yang berhadapan dengan hukum khususnya dengan ancaman hukuman dibawah 7 tahun dapat ditangani secara diversi terlebih dahulu dan dilanjutkan dengan restorative justice. Diversi ini berarti tidak dilakukan dengan cara pidana, melainkan dengan perdamaian melalui hubungan dengan korban dan keluarga dan pihak-pihak lain seperti penegak hukum dan pelaku. Sehingga dengan cara ini kasus yang dialami anakanak tersebut tidak masuk ke dalam ranah pidana. Restorative justice sendiri dilakukan dengan pemulihan, artinya ada lembaga-lembaga yang akan dibangun atau mengoptimalkan lembaga-lembaga yang telah ada oleh Kementerian Sosial. Sedangkan peran KPPPA sendiri lebih kepada proses koordinasi, monitoring dan evaluasi antar sektor dalam pemulihan tersebut. Sedangkan untuk kasus narkoba, pembunuhan dan pelecehan seksual tidak termasuk dalam UU SPPA karena ancaman pidana bisa lebih dari 7 tahun. Untuk itulah dibutuhkan peran orang tua dalam mendampingi dan membina anak-anaknya terhadap 3 kasus tersebut.

Diversi sebagai hal baru yang belum dikenal sebelumnya dalam peraturan perundang-undangan di Indonesia harus dilaksanakan secara cermat. Tata cara, pelaksanaan, monitoring dan evaluasinya harus diatur secara jelas sehingga tidak menimbulkan multitafsir dalam prakteknya. Sebagai hal baru, rawan terjadi penyalahgunaan dan penyimpangan.

Pasal 11 UU SPPA menegaskan bahwa kesepakatan diversi dapat berbentuk : a) Perdamaian dengan atau tanpa ganti kerugian; b) Penyerahan kemmbali pada orang tua/wali; c) Keikutsertaan dalam pendidikan atau pelatihan di lembaga pendidikan atau LPKS paling lama 3 (tiga) bulan; atau d) Pelayanan masyarakat.

Salah satu hal yang menarik dalam pasal tersebut adalah 
mengenai keikutsertaan anak dalam pendidikan atau pelatihan di lembaga pendidikan sebagaimana diatur dalam Pasal 11 huruf (d) UU SPPA. Bentuk kegiatan tersebut sedapat mungkin dikembalikan pada prinsip sistem peradilan pidana anak yang ditegaskan dalam Pasal 2 UU SPPA. Bentuk kegiatan harus diatur dan disusun secara mapan sehingga tidak menimbulkan multitafsir bagi aparat penegak hukum.

Berdasarkan latar belakang diatas, permasalahan dalam penelitian ini adalah bagaimana bentuk kegiatan diversi anak dalam sistem peradilan anak yang mencerminkan perlindungan bagi anak?

Tulisan ini merupakan hasil penelitian normatif dengan pendekatan peraturan perundangundangan (statute approach) dan pendekatan perbadingan (comparative approach).

\section{Hasil dan Pembahasan}

Bentuk Kegiatan Diversi dalam Undang-undang Nomor 11/2012 tentang Sistem Peradilan Pidana Anak dan di Australia

UU Sistem Peradilan Pidana Anak mengatur kriteria perkara yang dapat didiversi, dasar pertimbangan dilakukannya diversi, pelaksanaannya dapat dialkukan pada tiap-tiap tingkatan pemeriksaan dan pengawasan terhadap anak yang didiversi. Hal tersebut tertuang dalam Pasal 11 sampai dengan Pasal 15 UU Sistem Peradilan Pidana Anak.

Ketentuan Pasal 11 UU Sistem Peradilan Pidana menuangkan prinsip-prinsip KHA secara eksplisit adalah tepat. Karena prinsip-prinsip yang terkandung dalam KHA sudah seyogyanya menjiwai setiap peraturan perundang-undangan yang terkait dengan perlindungan anak di Indonesia. Namun penerapannya harus disesuaikan dengan keadaan di Indonesia. Penetapan prioritas perkara pidana yang dapat didiversi yang diatur dalam UU Sistem Peradilan Pidana Anak juga telah mencerminkan prinsip kepentingan terbaik bagi anak seperti dituangkan dalam Pasal 3 ayat (1) KHA.

Prinsip kepentingan terbaik bagi anak juga tertuang dalam Pasal 114 Rancangan Kitab Undang -Undang Hukum Pidana 2008 (RKUHP 2008), bahwa demi kepentingan masa depan anak, proses peradilan anak dapat 
ditunda atau dihentikan sama sekali. Prinsip demikian didasarkan pada ide diversi yang tertuang dalam Rule 11 dan Rule 17.4 The Beijing Rules. Pasal 114 RKUHP 2008 dikutip sebagai berikut :

Pasal 114

1) Dengan memperhatikan ketentuan mengenai tujuan dan pedoman pemidanaan sebagaimana dimaksud dalam Pasal 54 dan Pasal 55, demi kepentingan masa depan anak, pemeriksaan di depan pengadilan dapat ditunda atau dihentikan setelah mendengar pertimbangan penyidik, penuntut umum, dan Petugas Kemasyarakatan;

2) Penundaan atau penghentian pemeriksaan sebagaimana dimaksud pada ayat (1) disertai denngan syarat : a. anak tidak akan melakukan tindak pidana dan atau b. anak dalam waktu tertentu harus mengganti semua atau sebagian kerugian yang ditimbulkan akibat perbuatannya.

Selanjutnya, Pasal $12 \quad$ UU Sistem Peradilan Pidana Anak menekankan bahwa proses diversi dapat dilaksanakan pada tiap-tiap tahap pemeriksaan dalam proses peradilan pidana. Ketentuan pasal dapat dianggap sebagai pelaksanaan terhadap ketentuan Rule 11 The Beijing Rules yang menegaskan bahwa diversi dapat dilaksanakan di tiap-tiap tahap pemeriksaan dalam sistem peradilan pidana. Hal tersebut meliputi tahap pre judicial, judicial dan post judicial. Hal ini sejalan dengan pendapat Bernard J. Brown, bahwa diversi dapat dilakukan dalam setiap tingkatan pemeriksaan baik di tingkat penyidikan, penuntutan maupun persidangan dalam menyelesaikan perkara anak. Diversi dapat dilakukan dengan cara melakukan konseling (Brown, 1989:381).

Namun demikian, ketentuan yang tertuang dalam Pasal 12 UU Sistem Peradilan Pidana Anak dirasakan kurang tepat. Diversi seharusnya dilaksanakan pada pada tahap pre judicial. Hal ini dimaksudkan untuk melakukan pencegahan stigmatisasti sejak dini. Bila diversi dilakukan pada tahap judicial dan post judicial dalam 
dalam arti diversi dapat dilaksanakan di tiap-tiap tingkatan pemeriksaan, maka anak akan tetap terstigma karena proses peradilan pidana yang dijalaninya. Keinginan melakukan diversi harus ditekankan pada tahap awal. Polisi memiliki peranan penting dalam melakukan diversi.

Polisi harus diberi kewenangan penuh untuk menentukan layak tidaknya suatu perkara didiversi. Bila tindak pidana yang dilakukan oleh anak tergolong tindak pidana ringan, dan perbuatan menyimpang yang dilakukann di jalan, maka polisi dapat menyelesaikan perkara dengan cara informal. Anak hanya diberi peringatan (caution) dengan melibatkan peran orang tua atau wali sejak awal. Peranan orang tua sangat besar untuk perbaikan perilaku dan kondisi anak.

Bila tindak pidana yang dilakukan anak ancaman pidananya adalah lebih dari 1 (satu) tahun, maka polisi dapat melalukan teguran secara formal. Dalam hal ini orang tua juga dilibatkan, korban dan keluarganya juga dihadirkan. Polisi bertindak sebagai mediator dalam tahap ini. Untuk selanjutnya, dari pertemuan yang digelar, pelaku diminta untuk bertanggung jawab atas keadaan korban. Hasilnya dicatat dalam suatu sistem informasi yang tidak dapat diakses oleh masyarakat umum (bersifat rahasia). Dalam proses ini, anak dapat diikutkan dalam program-program tertentu untuk memperbaiki perilakunya. Program yang diikuti oleh anak disesuaikan dengan minat dan bakatnya.

Pasal 13 UU Sistem Peradilan Pidana Anak mengatur bahwa bila terhadap suatu tindak pidana dilakukan Diversi maka hasil kesepakatan tersebut berlaku sejak dicapainya kesepakatan yang dituangkan dalam penetapan diversi oleh hakim. Selanjutnya Pasal 14 UU Sistem Peradilan Pidana Anak menentukan pengawasan terhadap pelaksanaan hasil diversi dilakukan oleh BAPAS.

Pengaturan diversi secara khusus dalam UU Sistem Peradilan Pidana Anak di Indonesia dan implementasinya perlu memperhatikan ketentuan internasional.

Melalui upaya harmonisasi 
hukum, BPHN merekomendasikan, pertama, mengintroduksir hak-hak anak dalam Konvensi Hak-Hak Anak ke dalam perundang-undangan hukum nasional, kedua, peninjauan kembali hukum positif yang tidak sesuai dengan Konvensi Hak-Hak Anak, dan ketiga, melakukan identifikasi kemungkinan perlunya penyusunan peraturan-perundangundangan. Konsekuensinya menurut Erma Syafwan Syukrie, pemerintah Indonesia harus melakukan langkahlangkah harmonisasi hukum, yaitu: (1) memeriksa dan menganalisis perundang-undangan yang ada dan masih sedang dalam perencanaan/pembentukan;

meninjau ulang lembaga-lembaga yang berhubungan dengan pelaksanaan hak anak; mengusulkan langkah-langkah penyelerasan ketentuan Konvensi Hak-Hak Anak dengan perundangundangan lain; (4) meninjau ulang bagian perundang-undangan yang masih berlaku, tetapi perlu penyempurnaan atau pelaksanaan yang tepat; (5) memprioritaskan acara pembuatan undang-undang yang diperlukan untuk mengefektifkan pelaksanaan Konvensi Hak-Hak Anak atau penyelerasan dengan perundangundangan Indonesia. Pelaksanaan diversi di Indonesia dilakukan pada tingkat awal dalam sistem peradilan pidana, yaitu pada tahap pre judicial atau penyidikan. Hal ini mengingat polisi adalah aparat yang melaksanakan kontak awal dengan anak untuk mencegah terjadinya stigmatisasi sejak dini dan menghindarkan anak dari trauma yang terjadi bila proses peradilan anak berlangsung. Penyelesaian di luar jalur formal sesuai dengan Pasal 40 ayat (3) huruf b Konvensi HakHak Anak dan Pasal 5 Tokyo Rules. Sedangkan pengaturan penanganan oleh polisi pada tingkat awal sesuai dengan Penjelasan Rule 12 The Beijing Rules.

Selanjutnya, beberapa uraian terdahulu menunjukkan pentingnya penetapan syarat-syarat diversi anak dalam peraturan perundangundangan di Indonesia. Beberapa prinsip yang harus diperhatikan adalah :

1) Diversi harus dilaksanakan pada tahap pre judicial/ penyidikan. 
2) Diversi diutamakan bagi anak yang baru pertama kali melakukan tindak pidana;

3) Diversi wajib diterapkan bagi anak yang melakukan tindak pidana ringan. Bila anak melakukan tindak pidana yang lebih dari 1 tahun, maka diversi dapat dipertimbangkan pelaksanaannya.

4) Diversi memperhitungkan kerugian yang diderita korban akibat tindak pidana yang dilakukan anak.

5) Diversi dilakukan dengan sepersetujuan korban.

Dengan demikian, diversi tidak dapat diterapkan bagi seluruh tindak pidana. Penerapan diversi bagi anak yang melakukan tindak pidana ringan, bukan tindak pidana pembunuhan, kejahatan seksual. Untuk tindak pidana yang mengakibatkan hilangnya nyawa seseorang diversi harus benar-benar dipertimbangkan. Jenis tindak pidana yang dilakukan dan akibat yang ditimbulkan dari tindak pidana yang dilakukan oleh anak menjadi pertimbangan bagi polisi untuk melakukan langkah tepat dan menentukan bentuk diversi yang ditetapkan untuk anak. Hal ini sesuai dengan pengaturan Pasal 11 ayat (3) UU Sistem Peradilan Pidana Anak dalam melakukan diversi, aparat harus mempertimbangkan kategori kasus perkara dan kerugian yang ditimbulkaan oleh tindak pidana yang dilakukan anak.

UU Sistem Peradilan Pidana Anak belum mengatur secara konkrit mengenai bentuk kegiatan diversi bagi anak. Bentuk kegiatan diversi di Indonesia penting untuk diatur, terutama pada tingkat penyidikan.

Pasal ayat (1) 18 UU No. 2 Tahun 2002 tentang Kepolisian Republik Indonesia menyebutkan bahwa, untuk kepentingan umum pejabat Kepolisian Negara Republik Indonesia dalam melaksanakan tugas dan wewenangnya dapat bertindak menurut penilaiannya sendiri. Pada ayat (2), Pelaksanaan ketentuan sebagaimana dimaksud dalam ayat (1) hanya dapat dilakukan dalam keadaan yang sangat perlu dengan memperhatikan peraturan perundangundangan, serta Kode Etik Profesi Kepolisian Negara Republik 
Indonesia. Hal tersebut terkait erat dengan diskresi.

Diversi berbeda dengan diskresi, namun memiliki kaitan erat. Diskresi oleh kepolisian adalah suatu tindakan kepolisian berdasarkan atas penilaian sendiri seorang petugas polisi dalam rangka kepentingan umum. Dalam pelaksanaannya, tindakan diskresi tetap harus memperhatikan rambu-rambu aturan yang berlaku dan dapat dipertanggungjawabkan secara moral, tidak dimuati interes pribadi, serta harus terukur atau seimbang antara tindakan polisi dengan berat ringannya kesalahan serta tepat situasi. Diskresi merupakan "baju kepolisian" dalam menjalankan tugasnya. Diskresi dilakukan oleh petugas polisi di lapangan adalah untuk menyelaraskan situasi, dengan keharusan seorang polisi untuk bersikap tepat dan cerdas dalam perannya, tidak hanya sebagai penegak hukum, tapi sekaligus sebagai pelindung, pengayom dan pelayan masyarakat (Elfiana, 2009).

Sebagaimana diamanatkan dalam Rule 6 The Beijing Rules, bahwa diskresi dapat dilakukan di semua tingkatan dalam sistem peradilan pidana, baik pada tingkat penyidikan, penuntutan maupun persidangan. Diskresi merupakan bagian dari diversi.

Seperti telah diuraikan sebelumnya bahwa dalam proses peradilan anak, pertama-tama anak dihadapkan kepada aparat kepolisian. Kontak awal dengan penegak hukum ini sangat mempengaruhi tingkah laku selanjutnya dari tersangka anak. Pengalaman seorang tersangka dalam suatu proses tertentu mempengaruhi sikapnya terhadap proses berikutnya. Hal tersebut untuk menghindari rasa kecewa dan putus asa yang dapat mempengaruhi sikap anak selanjutnya. Hal ini sejalan dengan Rule 10.3. The Beijing Rules: kontak dengan badan penegak hukum dan anak-anak yang melanggar hukum harus diatur sedemikian rupa untuk menghormati status hukum dari anak tersebut, mempromosikan kelakuan baik dari si anak dan menghindari kesalahan yang membahayakan mereka, dengan memperhatikan keadaan kasusnya.

Aparat kepolisisan merupakan ujung tombak dalam pelaksanaan 
peradilan anak. Berdasar pada Pasal 16 (3) UU No. 23 Tahun 2002 juga menegaskan bahwa penangkapan, penahanan atau tindak pidana penjara anak hanya dilakukan apabila sesuai dengan hukum yang berlaku dan hanya dapat dilakukan sebagai upaya terakhir. Walaupun tidak ditegaskan mengenai diversi, namun atas dasar ketentuan Pasal $16 \quad$ (3) UU Pengadilan Anak, penyidik anak, jaksa anak dan hakim anak dapat mempertimbangkan pelaksanaan diversi dalam perkara anak.

Penyidik Anak harus memperhatikan Anak Nakal secara khusus. Pengertian khusus tersebut adalah menangani Anak Nakal secara simpatik, efektif, afektif dan melindungi serta mengayomi anak agar dapat menyongsong masa depannya yang lebih panjang itu lebih baik. Hal ini didasarkan pada fakta psikologis bahwa sifat emosional anak masih labil, sehingga diharapkan dengan pendidikan khusus Anak Nakal tidak mengalami frustasi yang berlebihan.

Melalui proses penyidikan ini, Penyidik Anak diharapkan mampu mengungkap berbagai informasi dari tersangka anak tanpa melukai fisik dan psikis dari tersangka anak tersebut dengan melakukan pendekatan secara efektif, afektif dan simpatik. Penyidik Anak harus berpengetahuan luas dan mendalam agar Berita Acara Pemeriksaan (BAP) dapat dibuat secara obyektif dan terhindar dari sewenang-wenang.

Penyidik anak perlu dibekali dengan pelatihan dan pendidikan khusus, sehingga dapat berpikir kreatif tentang kegiatan apa yang akan diberikan pada anak ketika aparat memilih untuk mendiversi suatu perkara. Sebagaimana diatur dalam Rule 12.1 The Beijing Rules. Pemberian pendidikan dan pelatihan khusus bagi aparat kepolisian yang berhubungan dengan anak ternyata berlaku juga di Jepang. Hal ini seperti yang diungkapkan oleh Shikita dan Tsichiya, bahwa: "Police work with juveniles is considered a specialized field and police officers working with juveniles are given special training" (Shikita dan Tsichiya, 1976:20). Penjelasan Rule 12 The Beijing Rules mengungkapkan, bahwa Rule 12 The Beijing Rules menggambarkan 
perhatian mengenai dibutuhkannya pelatihan-pelatihan khusus bagi semua penegak hukum yang terlibat dalam proses peradilan anak. Hal ini disebabkan karena polisi merupakan kontak awal dari sistem peradilan anak, maka sangat penting bagi mereka untuk bertindak sesuai dengan cara yang tepat sebagai tindakan pencegahan kontrol terhadap kejahatan anak dan penanganan pelanggaran yang dilakukan oleh anak.

Lebih lanjut Rule 22.1 The Beijing Rules menegaskan, bahwa pendidikan profesional dan model lain yang tepat yang diinstruksikan harus bermanfaat bagi perawatan profesional dari semua orang yang terlibat dalam perkara tindak pidana anak. Kemudian dalam Rule 22.2 The Beijing Rules menekankan, bahwa personil yang terlibat dalam peradilan anak harus memperhatikan berbagai perbedaan antara setiap anak, yang akan berhubungan dengan sistem peradilan anak. Usaha-usaha yang dilakukan harus mencerminkan perwakilan yang adil dari golongan wanita dan minoritas dalam peradilan anak.
Penjelasan Rule 22 The Beijing Rules menekankan, bahwa kekuasaan peradilan anak harus terdiri dari orang-orang dengan latar belakang yang berbeda (dalam berbagai sistem peradilan). Untuk itu dibutuhkan keahlian di bidang hukum, psikologi, kriminologi dan pengetahuan tentang perilaku. Kualifikasi profesional merupakan elemen penting dalam meyakinkan peradilan yang efektif dan tidak bersifat parsial. Lebih jauh diupayakan untuk meyakinkan kemungkinan dipilihnya petugas wanita dalam peradilan anak, dan kriteria yang digunakan akan diambil dari rekruitment, pelatihan, dan memfasilitasi wanita dalam peradilan anak.

Untuk keperluan penyidikan, penyidik anak dapat melakukan penahanan terhadap anak nakal, tetapi harus memperhatikan kepentingan anak terutama yang berkaitan dengan pertumbuhan dan perkembangan fisik, psikis dan kepentingan sosialnya. Hal ini sesuai dengan ketentuan Pasal 41 UU Pengadilan Anak: 
1) Penyidik wajib memeriksa tersangka dalam suasana kekeluargaan;

2) Dalam melakukan penyidikan terhadap Anak Nakal, Penyidik wajib meminta pertimbangan atau saran dari Pembimbing Kemasyarakatan, dan apabila perlu juga dapat meminta pertimbangan atau saran dari ahli pendidikan, ahli kesehatan jiwa, ahli agama atau petugas kemasyarakatan lainnya;

3) Proses penyidikan terhadap perkara Anak Nakal wajib dirahasiakan.

Ketentuan Pasal 41 ayat (3) UU Pengadilan Anak sejalan dengan Rule 21 (1) The Beijing Rules yang menetapkan, bahwa rekaman tentang perkara tindak pidana anak akan menjadi rahasia dan tertutup bagi pihak-pihak ketiga. Akses terhadap rekaman ini akan dibatasi hanya pada orang-orang yang terlibat langsung dengan persidangan atau petugaspetugas yang berwenang. Selanjutnya dalam Penjelasan Rule 21 The Beijing Rules dijelaskan, bahwa aturan tersebut berusaha untuk mencapai keseimbangan dalam benturan kepentingan yang berhubungan dengan rekaman tersebut, yaitu bagi para polisi, jaksa, dan kekuasaan peradilan lain, dengan kepentingan anak.

Anak merupakan pribadi yang belum matang baik secara fisik Sebuah perbadingan di South Australia, diversi dilaksanakan sebagai berikut.

\section{Bagan 5.1}

Tahapan tentang Juvenile Justice System di South Australia.

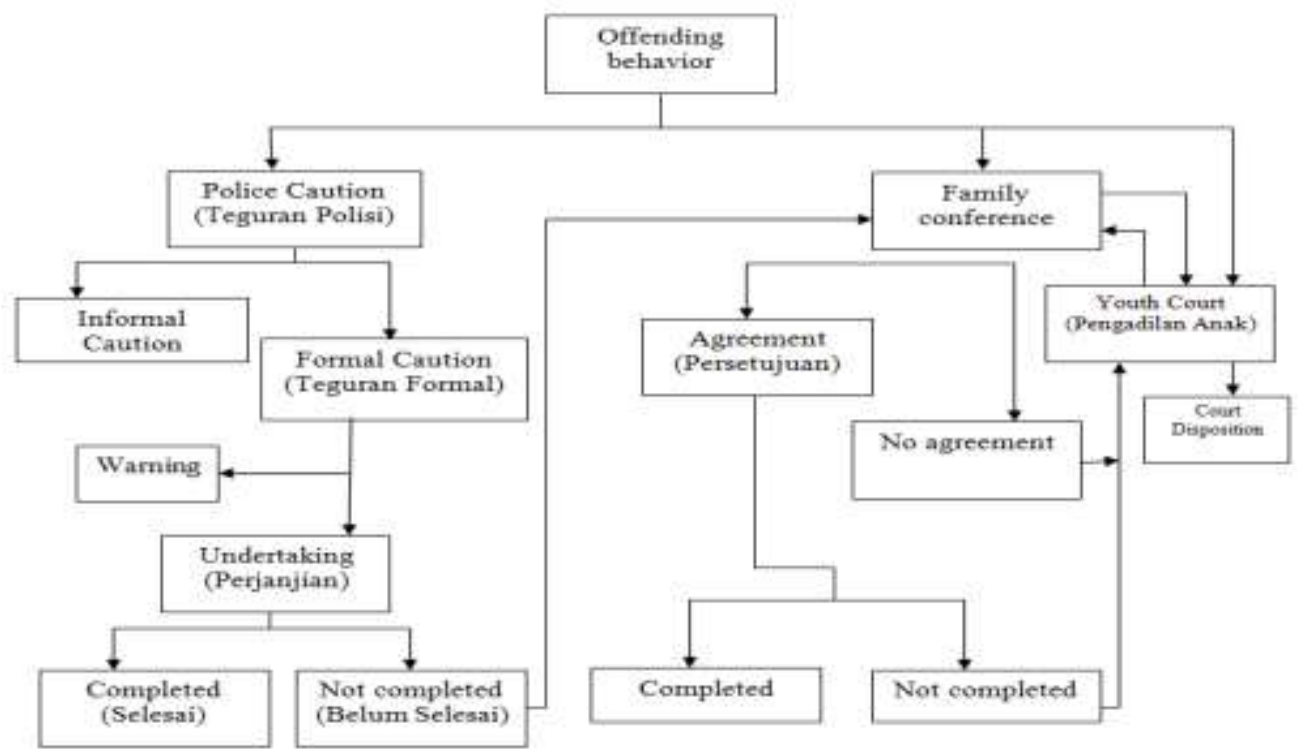


(Sumber: bahan hukum sekunder, dikutip dari Joy Wundersitz dan Nichole Hunter, Juvenile Justice in South Australia: Where Are We Now? Oscar Juvenile Justice. Information Bulletin. Office of Crime Statistics and Research. Januari 2005. No. 40, diolah).

Berdasarkan bagan di atas, diversi di South Australia ditujukan bagi anak yang baru pertama kali melakukan tindak pidana untuk menghindarkan mereka dari sistem peradilan pidana yang dapat memberikan dampak negatif bagi perilaku mereka selanjutnya. Diversi juga tidak diberlakukan untuk tindak pidana pembunuhan dan penganiayaan yang mengakibatkan kematian maupun luka berat. Diversi dilakukan sejak awal proses dengan menerapkan informal dan formal police cautions serta family conferencing untuk mendiversi perkara anak yang terjadi dan menghindarkan anak dari pengadilan. Payung hukum yang digunakan adalah Young Offenders Act 1993. Polisi sebagai gerbang awal dalam menangani perkara anak bergerak berdasarkan kerangka kerja sistem peradilan anak sesuai dengan Bagan 5.1 di atas.

Pada tahap Police Caution, polisi dapat memerintahkan pelaku untuk meminta maaf pada korban, membayar kompensasi pada korban dan menempatkan pelaku untuk menjalani kerja sosial (community work). Peran polisi sangat besar dalam sistem ini.

Pada tahap Family Conferences, polisi juga dapat menentukan sanksi berupa meminta maaf pada korban, membayar kompensasi pada korban dan menempatkan pelaku untuk menjalani kerja sosial (community work) dan bentuk lainnya sesuai kesepakatan antara pelaku dengan korban. Polisi dapat pula meneruskan perkara pada tahap Youth Court bila tahap Police Caution dan tahap Family Conferences tidak dapat menghasilkan penyelesaian. Hal ini diatur dalam The South Australia Young Offenders Act 1993 dalam Section 7 (4) ditegaskan:

A charge may only be laid - (a) if the youth requires the matter to be dealt with by the Court; or (b) if, in the opinion of the police officer, the matter cannot be adequately dealt with by the officer or a family conference because of the youth's repeated offending or some other circumstance of aggravation. 
The South Australia Young Offenders Act 1993 tidak memberikan ketentuan secara tegas tentang hal-hal yang dapat menjadi pertimbangan bagi polisi untuk memutuskan melakukan diversi bagi anak. Dengan demikian, polisi memiliki tanggung jawab untuk menentukan proses selanjutnya maupun mengurangi dan mencegah terjadinya pengulangan tindak pidana oleh anak yang dibuat dalam bentuk perjanjian pada tahap Police Caution maupun tahap Family Conferences.

Istilah Youth Court merupakan istilah baru. Sebelumnya, untuk menyebut peradilan anak dikenal istilah Children's Court. Pada tahap Youth Court, hakim dapat menjatuhkan sanksi berupa pidana penjara, pidana bersyarat, pidana kerja sosial, kewajiban melakukan hal-hal tertentu, pencabutan hak-hak tertentu, denda, kompensasi dan lainnya. Bila hakim menjatuhkan pidana penjara, maka tidak boleh dijatuhkan lebih dari 2 tahun. Seperti dikutip oleh Wundersitz dan Hunter dari pembukaan Young Offenders Act 1993 bahwa, "Prior to the introduction of the Young Offenders
Act 1993, the minimum length of detention which could be imposed by the then Children's Court was two month, while the maximum was two years" ( Shikita and Tsichiya, 1976: 17).

Selain South Australia, New South Wales dan Western Australia juga menerapkan diversi untuk mengurangi kontak anak dengan sistem peradilan pidana melalui conferencing dan atau cautioning, seperti dikutip berikut ini.

New South Wales, South Australia and Western Australia have introduced systems of conferencing and/or cautioning to reduce the overall rate of juvenile contact with the criminal justice system. In New South Wales, this is referred to as a Youth Justice Conference (YJC), in South Australia a Family Conference $(F C)$ and in Western Australia a Juvenile Justice Team (JJT). Conferences are facilitated by a trained conference convenor. Family members of the offender, the $\operatorname{victim}(s)$, members of the criminal justice system and other interested parties can attend, along with the offender. The offence and its impact on the victim(s) and the wider community are discussed, and the offender is encouraged to accept responsibility and negotiate some form of restitution (Snowball, 2008 $: 1,6)$.

Tindak pidana yang dilakukan oleh anak dan dan akibatnya bagi 
korban serta pengaruhnya bagi masyarakat dibicarakan dalam conferencing. Pelaku harus mempertanggungjawabkan perbuatannya dan membicarakan tentang restitusi bagi korban.

New South Wales, sebagai negara bagian terbesar di Australia, melaksanakan diversi dengan The New South Wales Young Offenders Act 1997 section 7. Diversi diharapkan tidak saja mampu mengurangi angka kriminal namun juga melindungi anak dari keterlibatannya dalam sistem peradilan seperti yang diungkapkan oleh Chan dan Zdenkowski dalam Weatherburn \& Baker berikut ini.

... one argument commonly made in favour of diversion is that it helps reduce dependence on more intrusive measures, such as imprisonment. On this account, the justification for diversion is not the fact that it is a better way of reducing crime but the fact it protects young people from iatrogenic forms of intervention, such as imprisonment. This is important point but sanction designed to reduce the use of imprisonment are more often promised than delivered in practice, at least in Australia. (Weatherburn dan Beker, 2001:61).

Program diversi dirancang bagi anak untuk menghindarkan anak sejak dini terhadap kemungkinan "criminal career" (Weatherburn dan Beker, 2001:62). Berikut ini dikutip Part 4 Section 19 dari The NSW Young Offenders Act 1997.

A formal police caution against further offending may be arranged and given in relation to an offence to a child who is alleged to have committed the offence, if:

(a) the offence is one for which a caution may be given, and

(b) the child admits the offence, and

(c) the child consents to the giving of the caution, and

(d) the child is entitled to be given a caution.

Polisi akan mempertimbangkan layak tidaknya suatu perkara untuk didiversi atau tidak berdasarkan kriteria yang dicantumkan dalam Section 20 (3) The NSW Young Offenders Act 1997 berikut ini.

(3) In considering whether it is appropriate to deal with a matter by caution, an investigating official is to consider the following:

(a)the seriousness of the offence,

(b)the degree of violence involved in the offence,

(c)the harm caused to any victim,

(d) the number and nature of any offences committed by the child and the number of times

(e)the child has been dealt with under this Act, 
(f) any other matter the official thinks appropriate in the circumstances.

Western Australia menjalankan diversi berdasarkan Young Offenders Act 1994. Section 23 (1) Young Offenders Act 1994 ditegaskan bahwa polisi tidak sekedar memberi peringatan (caution) pada pelaku, seperti dikutip berikut ini. ". . . unless because of the number of previous offences with which the person has been charged or for which the person has been dealt with under this Part it would be inappropriate only to give a caution."

Tindak pidana yang tidak dapat didiversi diatur dalam Schedules 1 and 2 Young Offenders Act 1994 yang meliputi tindak pidana kekerasan serius seperti pembunuhan, kekerasan seksual, kecelakaan yang menyebabkan matinya seseorang. Untuk dapat didiversi, pelaku harus memenuhi syarat yaitu baru pertama kali melakukan tindak pidana dan hal ini diatur dalam Section 29 Young Offenders Act 1994 berikut ini.

The types of offences that would render a caution inappropriate are specified under Schedules 1 and 2 of the Act and include serious violent offences (e.g. murder, sexual assault) as well as other serious offences (e.g. driving causing death). However, the number of previous offences that would render a caution inappropriate is not specified by the Act. ... Western Australia Young Offenders Act provides some guiding principles for the application of this option (under s 29) and endorses the use of JJTs for first offenders in particular (Snowball, 2008 : 1, 6).

Pelaku juga harus bertanggung jawab terhadap perbuatan yang dilakukannya, mengakui perbuatannya dan setuju dengan kesepakatan penyelesaian di luar jalur formal dalam hal ini adalah penyelesaian di luar pengadilan. Seperti diatur dalam section 25 (4) Western Australia Young Offenders Act yang dikutip dari Snowball berikut ini. "However, an important condition on the use of JJTs is that an offender can only be diverted to a JJT if they accept:...responsibility for the act or omission constituting the offence, and agrees to have the matter dealt with by a juvenile justice team rather than by a court" (Weatherburn dan Beker, 2001:61).

Diversi di Northern Territory baru diperkenalkan pada tahun 2000. Pelaksanaannya dilakukan oleh polisi 
dengan menyeleksi perkara-perkara anak yang akan didiversi dari proses peradilan menggunakan peringatan dan pertemuan, seperti hasil penelitian Cunningham berikut ini.

A juvenile pre-court diversion scheme was introduced in the Northern Territory in 2000. Administered by police, it uses warnings and conferences to divert selected juveniles from the court process. .... Police record on 3,597 apprehended juveniles over a 5 year period. Findings showed that the great majority of juveniles (76\%) did not reoffend within the first year after their initial diversion or court appearance. ... and the sceme was a response to both federal and international concerns that juvenile offenders in Northern Territoty werw unfairly treated by the criminal justice system (Cunningham, 2007:1).

Dengan demikian, perkara anak di Northern Territory tidak diadili melalui sistem peradilan pidana. Menurut Waite, Pre-court Diversion ini ditujukan bagi anak nakal yang berusia 10-18 tahun dengan tujuan sebagai berikut.

1) Provide and maintain an effective alternative to the prosecution and sentencing of young offenders in the formal justice system;

2) Encourage young offenders to be responsible members of the community by providing opportunities for positive bahavioural change and improvement in life skill through diversion activities (Waite, 2003).

Prinsip-prinsip berikut ini dikembangkan dalam pre-court diversion.

a) Treat young people fairly;

b) Support and involve victims;

c) Take account of impact on the victim;

d) Encourage parental responsibility;

e) Foster closer police and community interaction;

f) Foster positive social chance (Waite, 2003).

Polisi diberi kewenangan untuk melakukan diversi pada anak dengan cara lisan, memberikan peringatan secara tertulis atau mengadakan family/ victim-offender conference. Perbuatan diklasifikasikan dalam minor atau serius. Peringatan secara lisan (Verbal Warning) diberikan pada anak yang melakukan perbuatan dalam klasifikasi minor. Bila perilaku pelaku anak dianggap berbahaya bagi masyarakat maka, anak akan diberi peringatan secara tertulis (A Written Warning). Sementara Family dan VictimOffender Conferences diadakan untuk klasifikasi perbuatan serius seperti pembunuhan dan 
penganiayaan fisik yang menyebabkan luka parah dengan catatan pelaku dapat memilih tidak menerima diversi dan meneruskan perkara ke pengadilan (Cunningham, 2007:1). Dengan demikian tidak semua perkara dapat dilakukan diversi.

$\begin{array}{rcr}\text { Sementara } & \text { itu } & \text { Victoria } \\ \text { memberlakukan } & \text { program } & \text { diversi } \\ \text { sejak tahun } & 1989 & \text { dengan }\end{array}$
Magistrates' Court Act 1989 dalam Section 128A. Program ini diutamakan bagi orang yang baru pertama kali melakukan tindak pidana untuk menghindarkan criminal record dengan memberikan suatu kegiatan yang bermanfaat bagi pelaku, korban dan masyarakat sebagaimana dikutip berikut ini.

The Criminal Justice Diversion Program is Governed by Section 128 A of the Magistrate's Court Act 1989. The program provides mainly first time offenders with the opportunity to avoid criminal record by undertaking conditions that will benefit the offender, victim and the community as a whole. The program operates in all Magistrates' Courts throughout Victoria (Criminal Justice Diversion Program, 2009).

Program diversi dilakukan supaya korban dapat menerima restitusi dari pelaku, korban menerima permohonan maaf pelaku, mengurangi balas dendam dari korban pada pelaku, selanjutnya pelaku terhindar dari criminal record yang dapat berdampak pada stigmatisasi, perilaku pelaku dapat diperbaiki, memberdayakan peran masyarakat dalam penyelesaian masalah. Manfaat-manfaat tersebut seperti dikutip berikut ini.

a) Ensures that restitution is made to the victim of the offence if appropriate;

b) Ensures the victim receives an apology if appropriate;

c) Reduces the likehood of reoffending;

d) Assist offenders to avoid an accessible criminal record;

e) Assist in the provision of rehabilitation services to the offender;

f) Increases the use of community resources to provide counseling and treatment services;

g) Assist local community projects with voluntary work and donations (Criminal Justice Diversion Program, 2009).

Terdapat kriteria tertentu supaya diversi dapat diberlakukan dalam suatu perkara, yaitu:

a) The offence is triable summarily;

b) The offence is not subject to a minimum or fixed sentence or penalty (except demerit points);

c) The defendant acknowledges responsibility for the offense; 
d) There is sufficient evidence to gain a conviction (Criminal Justice Diversion Program, 2009).

Dengan demikian, di Victoria, suatu perkara dapat didiversi bila tindak pidana yang dilakukan merupakan tindak pidana yang ringan, bukan tindak pidana yang diancam dengan pidana penjara, pelaku bertanggungjawab atas kesalahannya dan terdapat cukup saksi.

Victoria mengenal Diversion Notice yang menyatakan bahwa suatu perkara didiversi. Dalam hal ini hakim pengadilan akan mempertimbangkan apakah suatu perkara layak didiversi atau tidak. Bila hakim menilai suatu perkara tidak layak untuk dilakukan diversi maka pelaku akan diproses ke Mention Court of the Magistrates' Court.

Korban akan dilibatkan dalam proses Court Hearing dalam proses diversi oleh koordinator penyelenggara diversi Korban akan diyakinkan, apakah ia setuju dengan prises tersebut, dikomunikasikan sejumlah kompensasi sebagai pengganti kerugian yang dialaminya dan sejauhmana tindak pidana yang terjadi berpengaruh terhadap kehidupan korban. Pengadilan akan memberikan pemberitahuan kepada korban tentang proses hearing tersebut.

Sebelum diajukan ke pengadilan, koordinator diversi akan meminta keterangan dari pelaku untuk mengidentifikasi masalah utama dalam perkara yang berjalan. Ia juga akan memberikan saran pada pengadilan tentang tindakan apa yang tepat untuk dijatuhkan pada pelaku.

Diversion hearing dilaksanakan dalam sidang terbuka. Hakim akan menetapkan program yang sesuai bagi pelaku untuk ditempatkan dalam The Criminal Justice Diversion Program and Diversion Development. Persangkaan akan dihentikan ketika Pogram diversi dimulai. Bila program telah selesai dijalankan, hasilnya dicatat dalam suatu bentuk catatan peringatan yang tidak dapat diakses oleh masyarakat umum.

Program pelaksanaan diversi di tiap-tiap Negara bagian di Australia berbeda-beda sesuai dengan 
kebijaksanaan masing-masing

wilayah, meliputi "verbal and written warning, formal cautions, victimoffender or family conferencing and referral to formal or informal community-based program" (Australian Human Rights Commission, 2009). Walaupun masing-masing negara memberikan syarat-syarat diversi dengan faktorfaktor yang berbeda namun segala pertimbangan diversi didasarkan pada jenis tindak pidana, berapa kali melakukan tindak pidana, sanksi, dan pelaku mengakui perbuatannya. Hal ini seperti yang diungkapkan oleh Snowball, bahwa:

There are two things worth nothing about all these provisions. The first is that the discretion available to police and courts in relation to whom they choose to divert is rather wide. None of the schemes contains a complete list of the factors that police and courts must or can take into account when deciding whether to caution a young offender. This makes it impossible to determine whether differences in rates of juvenile diversion can be explained solely in terms of legal factors. The second is that, although each state requires attention to different factors, all states place considerable emphasis on:

a) the offence type b) the number of previous contacts

c) the type of previous penalties

d) whether the offender admits the offence (Snowball, 2008: $1,6)$.

Di Queensland, Police Cautioning telah digunakan untuk melakukan diversi sejak tahun 1963. Program ini ditujukan bagi anak usia 10 sampai 17 tahun, seperti dikutip berikut ini.

In Queensland, police cautioning has been the primary method of Diversion of juvenile offenders from formal criminal justice processing since 1963. Cautioning programs have been introduced in various other Australian Jurisdictions since this time. In excess of 11,000 juveniles, that is children between ten and seventeen years of age, were formally cautioned in Queensland in 1990-91 for a range of criminal and quasi-criminal offences (Lewis dan O'Regan, 2009:1).

Secara umum diversi diatur dalam Queensland Juvenile Justice Act 1992, namun secara khusus program diversi diatur dalam aturan yang dibuat oleh lembaga kepolisian di Queensland.

Kewenangan polisi untuk melakukan Police Caution didasarkan pada diskresi dalam common law system. Diskresi memberikan suatu kebebasan bagi 
polisi untuk menentukan apakah terhadap seseorang yang melakukan suatu tindak pidana akan diproses menurut hukum yang berlaku atau tidak. Kewenangan diskresi bagi polisi telah diformalkan dalam Juvenile Justice Act 1992.

Tujuan dari caution diatur dalam Section 14 Juvenile Justice Act 1992., yaitu untuk mengalihkan penyelesaian anak yang terlibat dalam tindak pidana di luar peradilan. Berikut ini kutipan Section 14.

(14) Purpose of caution

The purpose of this division is to set up a way of diverting a child who commits an offence from the courts' criminal justice system by allowing a police officer to administer a caution to the child instead of bringing the child before a court for the offence

Prosedur Caution termasuk juga penjelasan kepada anak tentang tujuan, jenis dan pengaruhnya dari pemberian caution terhadapnya. Langkah yang diambil dapat berupa penjelasan masalah kepribadian anak, pelatihan bagi anak dan penyediaan penterjemah seperti ditegaskan dalam section 18 Juvenile Justice Act 1992.

\section{(18) Caution procedure must involve explanation}

(1) A police officer who administers, or requests the administration of, a caution to a child must take steps to ensure that the child and the person present under section 16 (2) understand the purpose, nature and effect of the caution.

(2) The steps that can be taken include, for example-

(a) personally explaining these matters to the child; and

(b) having some person with training or experience in the cautioning of children give the explanation; and

(c) having an interpreter or other person able to communicate effectively with the child give the explanation; and

(d) supplying an explanatory note in English or another language.

Caution juga dapat berupa permohonan maaf dari pelaku terhadap korban (section 19 Juvenile Justice Act 1992). Caution tidak termasuk dalam catatan kriminal anak. Hal ini ditegaskan dalam Section 21 (4) Juvenile Justice Act 1992 bahwa, "The caution is not part of the child's criminal history"

Peringatan (caution) pada keadaan normal hanya diberikan pada orang yang baru pertama kali melakukan tindak pidana, namun dalam prakteknya tidak demikian. "Normally, cautions are administered for the first offence 
which comes to police attention. However, if the offences are separated by time and the circumstances warrant it, the child may receive more than one caution" (Lewis dan O'Regan, 2009 :1).

Cautioning merupakan tindakan formal yang diambil oleh petugas kepolisian yang telah terlatih. Proses tersebut meliputi diskusi antara polisi dengan lembaga pemerhati anak dan secara terpisah juga dilakukan pemanggilan terhadap anak dan orang tua anak. Hal ini penting sekali dilakukan untuk menggali informasi tentang perilaku anak.

Anak yang telah diberi peringatan dicatat dalam catatan kepolisian atau sistem informasi kepolisian. Bila anak melakukan lagi perbuatannya, catatan tersebut menjadi dasar bagi polisi untuk menentukan sikap selanjutnya.

Dikenal pula informal caution dalam diversi di Queensland. Informal caution diberikan pada anak yang melakukan perilaku menyimpang di jalanan dan pelanggaran aturan lalu lintas yang ringan. Informal caution tidak dicatat dalam sistem informasi kepolisian dan orang tua tidak dilibatkan dalam penyelesaian masalah ini, seperti dikutip dari Lewis berikut ini.

Police can and do administer informal cautions for behaviour, particularly for street offences and minor traffic infringements. While technically constituting offences, these are most effectively dealt with at the time of the event and do not warrant further action. This type of caution is not recorded and normally would not involve the juveniles' parents. However, in appropriate cases, such as an intoxicated child, the child may be taken home and/or the parents contacted. Such cautions are not recorded and are administered "on the spot" (Lewis dan O'Regan, 2009 :3).

Leivesley dan O'connor mengungkapkan bahwa sejumlah penelitian menyarankan bahwa diversi dilakukan dengan melaksanakan cautioning programs untuk mencegah keterlibatan anak dalam proses peradilan pidana. "Numerous studies have examined the nature of juvenile offending and have recommended that diversionary schemes, primarily cautioning programs, be implemented to prevent children entering the formal criminal justice process" (Lewis dan O'Regan, 2009: 3). Selain biayanya 
yang murah, Cautioning program sebagai salah satu bentuk diversi mampu menghindarkan efek negatif dari sistem paradilan pidana bagi anak.

Queensland memiliki petugas khusus menangani anak. Petugas tersebut terlatih dan professional sehingga dapat membangun hubungan baik dengan anak dan remaja, seperti dikutip berikut ini.

In acknowledgment of special issues involving children, the Queensland Police Service has police who specialise in dealing with juveniles. The Juvenile Aid Bureau is a dedicated functional area dealing with juveniles. It is staffed by police who have a genuine interest in working and dealing with youth. Juvenile Aid Bureau personnel have greater experience and generally a more professional and sensitive relationship with children and youth. Programs have been developed which encourage positive youth/police interactions (Lewis dan O'Regan, 2009 :6).

Polisi Queensland juga mengembangkan fasilitas bagi anak untuk 4 (empat) jenis aktifitas yaitu olahraga, rekreasi, youth and community assistance programs dan kesenian. Fasilitas-fasilitas tersebut juga digunakan untuk mendukung kegiatan program diversi.
The Queensland Police-Citizens Youth Welfare Association, which is partially resourced by the Queensland Police Service but is community based and controlled,provides a network of facilities which service youth and provide activities for young people in general. It is presently attempting to focus its response on youth at risk. Its thirty-one clubs scattered throughout the state offer four different types of activity units which are directed primarily at young people:

(a) sport activities;

(b) recreational activities;

(c) youth and community assistance programs; and

(d) cultural/passive activities.

Activities include a youth diversion program where young offenders who have been cautioned by the Juvenile Aid Bureau are given the opportunity to attend adventure based training.( Lewis dan O'Regan, 2009 : 7).

Berdasarkan uraian di atas, bentuk pelaksanaan diversi di tiaptiap Negara bagian di Australia berbeda-beda sesuai dengan kebijaksanaan masing-masing wilayah. Bentuk kegiatan diversi dapat berupa penentuan kegiatan yang bermanfaat bagi pelaku, korban dan masyarakat. Selain itu anak juga dapat diarahkan untuk mengikuti pelatihan dan ketentuan untuk mengikuti beberapa aktifitas. Hal tersebut dapat dilihat di Victoria 
yang memberlakukan program diversi sejak tahun 1989 dengan Magistrates' Court Act 1989 dalam Section 128A. Program ini diutamakan bagi orang yang baru pertama kali melakukan tindak pidana untuk menghindarkan criminal record dengan memberikan suatu kegiatan yang bermanfaat bagi pelaku, korban dan masyarakat

Sementara itu di Queensland, bentuk kegiatan diversi yang dilaksanakan dapat berupa penjelasan masalah kepribadian anak, pelatihan bagi anak dan penyediaan penterjemah. Caution juga dapat berupa permohonan maaf dari pelaku terhadap korban. Queensland juga mengembangkan fasilitas bagi anak untuk 4 (empat) jenis aktifitas yaitu olahraga, rekreasi, youth and community assistance programs dan kesenian. Fasilitas-fasilitas tersebut juga digunakan untuk mendukung kegiatan program diversi.

Walaupun pengaturan dan bentuk kegiatan diversi di masingmasing Negara bagian di Australia berbeda-beda, namun beberapa negara bagian menekankan peranan penting polisi sebagai gatekeepers dalam pelaksanaan diversi. Di South Australia, New South Wales, Western Australia, Queensland dan Northern Territory, polisi memiliki kewenangan dalam memberikan peringatan pada anak baik bersifat informal maupun formal sesuai dengan tingkat berat ringannya tindak pidana yang dilakukan oleh anak. Sementara itu di Victoria, pelaksanaan diversi dilakukan oleh Magistrates Court. Pengaturan bentuk diversi di Australia dapat menjadi pertimbangan masukan bagi pemerintah Indonesia untuk menentukan bentuk diversi yang tepat diberikan bagi anak dalam rangka pencegahan stigmatisasi dan demi kepentingan terbaik bagi anak.

Indonesia dapat mempertimbangkan penggunaan peringatan non formal dan peringatan formal dalam diversi seperti telah dilakukan di Australia. Setelah itu, polisi dapat menetapkan beberapa kegiatan yang harus diikuti oleh anak terkait dengan penggunaan diversi bagi anak. Kegiatan tersebut dapat berupa olahraga, rekreasi, assistance programs dan kesenian. Namun 
demikian penetapan bentuk kegiatan tersebut harus menyesuaikan dengan kebutuhan anak agar adak dapat berkembang menjadi lebih baik dan bermanfaat bagi masa depan anak.

Sebuah hasil penelitian terdahulu yang dilakukan oleh Nurini dkk menunjukkan bahwa diperlukan strategi dalam menghadapi pemberlakuan UU SPPA. Strategi dalam menentukan bentuk kegiatan bagi anak yang didiversi tersebut berbeda-beda di tiap kota maupun daerah. Hal ini disebabkan karena luasnya wilayah Indonesia dengan berbagai macam karakteristik (Aprilianda, dkk., 2012).

Polres Malang Kota dalam menentukan bentuk kegiatan diversi yang diberikan pada anak telah bekerjasama Dinas Sosial. Dalam hal pelaku tindak pidana anak butuh untuk diberi keterampilan dengan menempatkannya Panti Sosial dan Petirahan Anak "Bima Sakti" di Batu, selanjutnya dijalin pula kerjasama dengan dinas pendidikan dalam hal ini Sekolah dalam hal memantau perkembangan anak nakal pasca didiversi. Kegiatan tersebut mencerminkan karakteristik Malang sebagai kota pendidikan sehingga anak diarahkan pada lembagalembaga pendidikan tertentu untuk kepentingan terbaik bagi anak. Bentuk diversi lainnya yang selama ini diterapkan oleh Polres Malang Kota adalah wajib lapor bagi pelaku sebagai shock therapy ( Aprilianda, dkk., 2012).

Sementara itu Polres Malang di Kepanjen memiliki koordinasi dan kerja sama yang baik dengan Pusat Pelayanan Terpadu Pemberdayaan Perempuan Dan Anak (P2TP2A) Kabupaten Malang, hingga nampak lebih siap dalam menghadapi keberlakuan UU SPPA pada tahun 2014. Polres Pasuruan juga menggandeng Pusat Pelayanan Terpadu Perlindungan Perempuan dan Anak(PPT-PPA) dalam hal korban tindak pidana adalah anak dibawah umur, meski koordinasi yang dilakukan belum maksimal karena kurangnya political will dari pemerintah daerah Kabupaten Pasuruan, namun sudah mulai disiapkan kerja sama lain dengan dinas sosial dan LSM untuk menghadapi UU SPPA ( Aprilianda, dkk., 2012). 
Pelembagaan diversi berbasis Social Responsibilty dapat dilakukan dengan pelibatan aparat penegak hukum dan pemerintah daerah sebagaimana amanat UU SPPA, Pusat Pelayanan Terpadu Pemberdayaan Perempuan Dan Anak (P2TP2A) di Kabupaten Malang, misalnya, meski masih belum maksimal karena hanya fokus pada korban anak dan belum menyentuh anak sebagai pelaku, namun kinerja lembaga ini cukup baik karena mendapatkan dukungan dari Pemerintah Daerah. Program yang sudah ada dalam lembaga tersebut dapat dikembangkan juga pada anak yang berkonflik dengan hukum dengan turut juga merumuskan pendidikan atau pelatihan bagi anak yang berkonflik dengan hukum di lembaga pendidikan atau LPKS paling lama 3 (tiga) bulan atau pelayanan masyarakat yang nantinya disesuaikan dengan karakteristik daerah (Aprilianda, dkk., 2012).

\section{Simpulan}

Bentuk pelaksanaan diversi di Indonesia dapat dipertimbangkan melalui pengembangan pendidikan dan pelatihan bagi anak misalnya fasilitas bagi anak untuk 4 (empat) jenis aktifitas yaitu olahraga, rekreasi, assistance programs dan kesenian. Di Indonesia, kegiatan tersebut dapat dilakukan dengan menjalin kerjasama dengan dinas sosial dan LSM. Selanjutnya kegiatan yang diberikan pada anak disesuakan dengan karakteristik daerah dan menyesuaikan bakat dan minat anak.

\section{Daftar Pustaka}

Bernard J. Brown, 1989, Juvenile Offenders reviewing : Seymour, John., Dealing With Young Offender, Sidney, Law Book co.

Elfiana, Malakah Penyelesaian Kasus Anak Melalui Diversi Dan Restorative Justice, 2009, Poltabes Banda Aceh, Tanggal 31 Maret 2009.

Shikita and Tsichiya, UNDSRI (United Nations Social Defence Research Institute), 1976, Februari, Juvenile Justice an International Survey, Country Reports, Related Materials and Suggestions for future Research, Publication No.12, Rome,

Snowball,Lucy, 2008, Diversion Of Indigenous Juvenile Offenders, Trends \& Issues in Crime and Criminal 
Justice. Woden: Jun 2008. , Iss. 355.

Australian Human Rights Commission. Best Practice Priciples for the Diversion of Juvenile Offenders. Human Rights Brief No. 5 (2001), diakses dari http://www.hreoc.gov.au/Hu man_Rights/Briefs/brief_5.h $\underline{\mathrm{tml}}$

Hasil Penelitian Nurini Aprilianda, dkk., 2012. Desain Pelembagaan Diversi Dalam Perkara Anak Berbasis Social Responsibility ( Studi Pada Tiga Kepolisian Resort Kota/Kabupaten di Jawa Timur), Penelitian Hibah Bersaing Institusi Batch II, Unibraw.

Jurnal :

Cunningham,Teresa, Pre-Court Diversion in the Northern Territory: Impact on Juvenille Reoffending. Trends \& Issues in Crime and Criminal Justice. Woden: Juni 2007., Iss. 339.

Don Weatherburn dan Joanne Beker, Transient Offenders in 1996 Secondary School Survey : a Cautionary Note on Juvenile Justice Diversion, 2001, h. 61, diakses dari heinonline 13 Current Issues Criminal Justice, 60, 20012002.

Lewis, Ann dan Clement O'Regan, Police Cautioning Effective Diversion Or Expedience?, National Conference on
Juvenile Justice , h. 1, diakses dari HeinOnline.

Waite,G., A Preventive and Restoratice Approach to Juvenile Offending, 2003, Papeer presened to Fourth National Conference on Conferencing, Circles and other Restorative Practices, Velhoeven, Netherlands, 2830 August 2003.

Peraturan Perundang-undangan:

Undang-undang Nomor 23 tahun 2002 tentang Perlindungan Anak.

United Nations Convention on the Rights of the Child

United Nation Standard Minimum Rules for the Administration of Juvenile Justice (The Beijing Rules)

United Nations Rules for The Protection of Juvenile Deprived of Their Liberty (UNRPJ).

United Nations Standard Minimum Rules for Non-custodial Measures (Tokyo Rules)

Telegram Rahasia Kabareskrim Polri Nomor : TR/1124/XI/2006 